Albert K. Boekhorst

\title{
Towards an Information Democracy: A Research Agenda
}

\begin{abstract}
:
People, organisations and societies need knowledge to satisfy their needs so they can survive and develop themselves and move forward in time and space. Knowledge on themselves, their social and their physical surrounding. Those who are better than others capable to satisfy their information needs in an effective and efficient way, and participate in the relevant information networks are more capable to survive and develop themselves than those with less advantageous traits. However, there are barriers that complicate or can even block the successful access to needed information and to the information economy. Four types of potential barriers that are based on interdependencies between people: economic, political, affective and cognitive are described.
\end{abstract}

\section{Agenda}

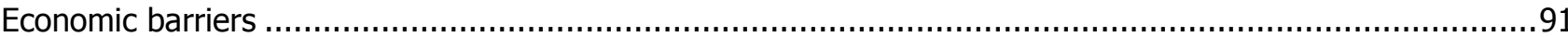

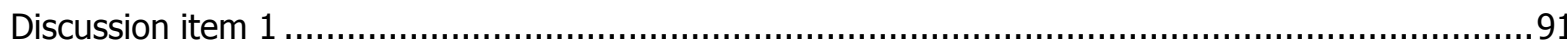

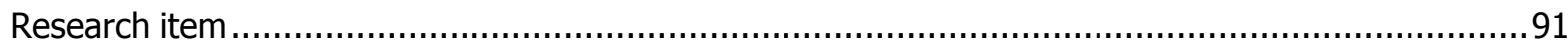

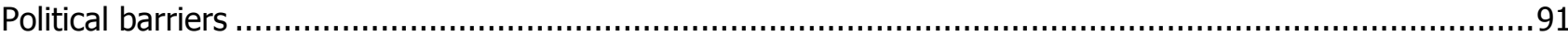

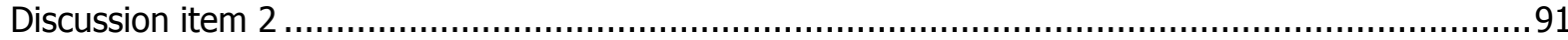

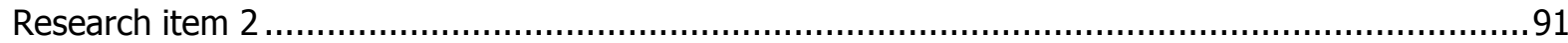

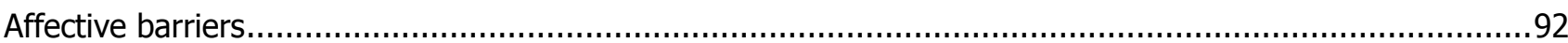

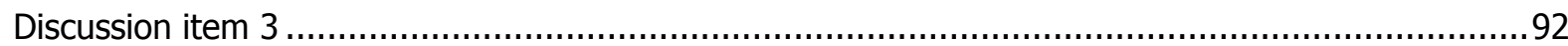

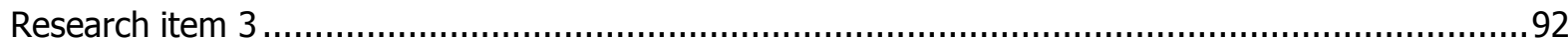

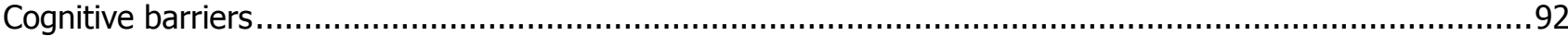

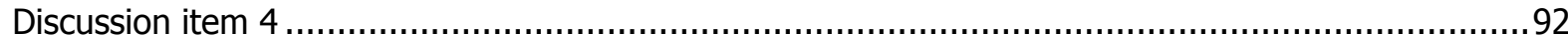

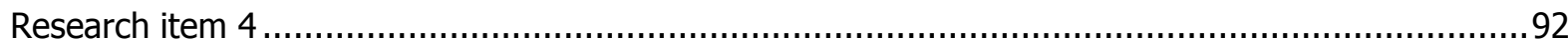

\section{Author:}

Albert K. Boekhorst:

- Universiteit van Amsterdam, Mediastudies, Turfdraagsterpad 9, 1012 XT Amsterdam, Netherlands. University of Pretoria, South Africa and Talliin University, Estonia

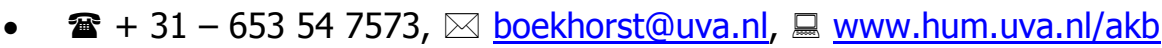


People, organisations and societies need information to satisfy their needs so they can survive and develop themselves and move forward in time and space. Knowledge on themselves, their social and their physical surrounding. Those who are better than others capable to satisfy their information needs in an effective and efficient way, and participate in the relevant information networks are more capable to survive and develop themselves than those with less advantageous traits.

However, there are barriers that complicate or can even block the successful access to needed information and to the information economy. We distinguish four types of potential barriers that are based on interdependencies between people: economic, political, affective and cognitive.

\section{Economic barriers}

Economic relations refer to the fact that people are dependent on the production and the distribution of scarce resources including food, clothing and housing. Information can also be seen as a quantifiable unit to which one can assign a value depending on supply and demand. Since the seventies of the 20th century, information is often seen as the fourth production factor, which functions as the driving force of the economy. This means the application of supply and demand factors are applicable to the production, use and control of information. This includes not only the information itself, but also the infra-structure that is needed. At the same time producing information products is relatively much more profitable than industrial or agricultural ones. As information needs a carrier and an infrastructure, we distinguish content, technical infrastructure and a social infrastructure. For each of these elements the laws of supply and demand are applicable.

\section{Discussion item 1}

The uneven distribution of wealth in the world leads to differences in infra-structure and the possibility to 'buy' and 'sell information products. This is relevant for both the technical infrastructure as the social infrastructure. The information economy is dominated by 'western' countries. For information products this can be demonstrated by checking ISSN, ISBN and patents by country. 'Digital divide' is mainly an 'economic' problem.

\section{Research item}

The implementation of 'Open source software' and 'Academic Repositories' for scientific information, suitable for the African situation should be investigated. Next to that there is a need for possibilities of affordable access to general information for development and recreation.

The World Bank offers annual World Development Reports (WDR). They offer invaluable access to the economic, social and environmental state of the world today. Each year the WDR provides in depth analysis of a specific aspect of development

\section{Political barriers}

Political relations are the effect of people's need to protect themselves against physical constraint and aggression of others. To obtain this a regulation of violence is needed whereby specialists can enforce their power. Hereby the law and order of a society is formally stipulated. These rules have reference to all relation's people have with each other. Laws regarding information are for example regulation on author's rights, archive laws, access to government information and freedom for the press. These legislations can be seen as political regulations through which access to certain types of information is controlled.

\section{Discussion item 2}

The access to information is not guaranteed in all countries in the same way. Some countries have legislation which entitles citizens access to government information and/or to files on themselves while others has not.

\section{Research item 2}

An comparative investigation into the 'openness' to (government) information and legislation into information privacy can lead to insight into formal barriers to information. Both for retrieval and dissemination.

'Over seventy countries around the world have implemented some form of freedom of information legislation.' (Wikipedia) 


\section{Affective barriers}

Affective relations refer to the fact that people have feelings for each other. People need each other for affection, love and support. These friendships and emotional relations are not limited only to other people, but also include objects and organisations that are appropriate to a person's culture. Computers and other information sources such as books, computers, CD's and television are also included. This linking has reference to not only the information type, but also the information itself. For example, differences in the appreciation for diverse forms of ballet and poetry are noted from the sales figures of books/ magazines and the user records of the public library. And of course emotional factors such as anxiety, frustration and confidence does influence the searching process.

\section{Discussion item 3}

The format in which information is made public can influence the ease of access for people and the chance to sell it. Information products and transfer are mainly based on (digital) texts and is not very accessible for persons and societies with an oral tradition. The law of less effort is also applicable here.

\section{Research item 3}

Research is needed how to access people who need information for development from printed and digital resources, while they were brought up in a orally tradition.

Among others Kuhlthau and Dervin have given attention to the emotional aspects in search processes.

\section{Cognitive barriers}

Cognitive relations refer to the fact that people are dependent on each other because they learn from each other. People create knowledge and distribute this between each other in the form of information. Up to the development of writing, people communicated mainly through speech and verbal communication. Writing and printing made it possible for information to be disseminated in spite of borders of time and space. Learning from each other happens in diverse ways and is not limited to education at school. The scope and content that is taught to the people depend on their social position and societal relations. An illiterate farm worker in the 18 th century was not as affected by his illiteracy as an illiterate person in the first decade of the 21st century in Western society. To be able to survive and develop themselves people, organisations and societies need to be information literate. Information literacy is strongly connected with Life Long Learning. National governments should give attention to the recognition of lifelong learning and information literacy as key elements for the development of generic capabilities which must be required for the accreditation of all education and training programs.

\section{Discussion item 4}

Ongoing technization, differentiation and globalisation (Informatization process) lead to an explosion of information accessible via a variety of information media and channels. More skills and knowledge than ever before is needed to locate and select and evaluate information needed to satisfy a persons' information need to be able to move forward in time and space. Being able to distinguish information needs and to be able to satisfy these needs effectively and efficiently is called being 'information literate'. The Informatization process asks for continuing attention for information literacy in all phases of formal and informal schooling to prepare them for a successful Life Long Learning and empower them to be adequate members of their society.

\section{Research item 4}

Tools should be developed for the implementation of information literacy into the regular curriculum's of schooling. The role of school, public and academic libraries should be make clear.

The Alexandria Proclamation on Information Literacy and Lifelong Learning offers an excellent departure for assessment and implementation of integrated information literacy into all levels of schooling.

\section{References}

Beacons of the Information Society. The Alexandria Proclamation on Information Literacy and Lifelong Learning. http://www.ifla.org/III/wsis/BeaconInfSoc.html

Boekhorst, Albert Klazes. 2000. Informatievaardig worden in het onderwijs, een informatiewetenschappelijk perspectief een vergelijkende gevallenstudie in Nederland en Zuid-Afrika. Pretoria: University of Pretoria. (Available at 
http://upetd.up.ac.za/thesis/available/etd11082004-111737/unrestricted/00thesis.pdf)

Britz, J.J., Lor, P.J., Coetzee, E.M.I. \& Bester, B.C. 2006. Africa as a knowledge society: a reality check. International Information and Library Review, 38(2006): 25-40.

Kuhlthau, Carol Collier. 2004. Seeking meaning : a process approach to library and information services. Westport, CT [etc.] : Libraries Unlimited

Dijk, Jan van. 2005. The Deepening Divide, Inequality in the Information Society. Thousand Oaks, London, New Delhi: Sage, 240 p.

Hamelink, Cees J. 2000. The ethics of cyberspace. London [etc.] : Sage Publications.

Julien, H., McKechnie, L. \& Hart, S. 2004. "A content analysis of affective issues in library and information science systems work" [Summary of a research note delivered at the ISIC 2004 conference, Dublin, 1-3 September, 2004] Information Research, 10(1) summary 6 (Available at http://InformationR.net/ir/10-1/abs6)

The World Bank. World Development Report 2007: Development and the Next Generation (Available http://econ.worldbank.org/WBSITE/EXTERNAL/ EXTDEC/EXTRESEARCH/EXTWDRS/EXTWDR200 7/0, contentMDK:21055591 menuPK:1489854 pagePK:64167689 piPK:64167673 theSitePK:1 489834,00.html)

World Economic Forum. (2003). Gearing Africa for the knowledge economy, African Economic Summit. Retrieved October 13, 2004 from http://www.weforum.org/site/knowledgenavigat or.nsf/Content/Gearing\%20Africa\%20.

Wikipedia: Freedom of information legislation http://en.wikipedia.org/wiki/Freedom of Inform ation Act 